\title{
WHAT WE REMEMBER AND WHAT WE FORGET: SELECTIVE MEMORY IN THE HOLOCAUST
}

\author{
Maya Camargo-Vemuri \\ Adjunct Professor, United States Naval Academy \\ PhD Candidate, Johns Hopkins University, USA \\ mcamarg2@jhu.edu
}

\begin{abstract}
Why remember atrocity? This paper considers how trauma shapes the political memory of atrocity. What we choose to remember about atrocity is largely determined by the visibility of events, but also impacted by social norms, normalized violence, and perceptions of atrocity. Certain events, although common or not necessarily unusual, are suppressed from memory (both in collective and individual narratives) due to fear, shame, guilt, or disgust. In genocide, we rarely hear about acts that induce emotions such as the ones mentioned, including acts of rape, prostitution, and parricide. Most often, such acts are omitted from the narrative because they are not normal crimes in the societies where they occur, and are seen as particularly horrific. The consequence of this omission is a skewed image or conception of genocide and what it does to the people who are part of it, either as victims or perpetrators. This paper determines that, however uncomfortable, unusual, or painful it is to remember such acts, the memory of such acts is necessary to understand the mechanics of atrocity and victimization. It uses a case study of the Holocaust, focusing on sexual violence, to illustrate the concepts of memory omission, skewed historical perception, and the necessity of understanding atrocity through accurate memory.
\end{abstract}

Keywords: atrocity, genocide, Holocaust, narratives, political memory, sexual violence, trauma, victimization

\section{INTRODUCTION}

Why do we choose to remember some things in political memory and forget others? When we think of remembering and forgetting in atrocity, we are often confronted with especially traumatic and taboo experiences, which are often suppressed in memory for many reasons. Private emotions, public responses, and the interests of historians are but a few explanations for this suppression. 
This paper looks at how trauma shapes political memory, specifically in the case of genocide. It considers what we choose to remember (or forget) in cases of genocide, and why we make these choices. To illustrate how trauma shapes memory and how some events are selectively forgotten, this paper uses a case study from the Holocaust, looking at sexual violence in memory. In particular, the author focuses on rape, prostitution, and reproductive violence as aspects that have been suppressed in the political memory of the Holocaust but are necessary to remember.

\section{NEUROPSYCHOLOGICAL AND POLITICAL MEMORY}

In general, when we speak of history, we speak not only of events that have transpired in the past, but of memory - more specifically, political memory. Political memory can be defined as one or more of the following: a) collective memory as interpreted through a political lens; b) collective memory of a political event; or c) collective memory as expressed by social and/or political institutions (Verovšek 2016). Due to its ties to political events, actors, and institutions, political memory is particularly important to the way in which certain events wars, revolutions, regime change, etc. - are remembered and memorialized. Consequently, political memory is a way of capturing the Zeitgeist surrounding a politically defining event, through the eyes of the people.

However, as is often noted about history, it is written by the victors, or at very least, the survivors. This means that collective memory is not always truly collective, but rather composed of the stories of those who managed to survive, win, or both. Even so, collective memory is not always the full memory of those who survive, as some survivors and victors choose to omit details of their experiences that are then lost to history.

\section{REMEMBERING, FORGETTING, AND MEMORY}

Before proceeding, we must separate memory as a cognitive process from memory as a historical process. When we speak of memory as a cognitive process, we are referring to neuropsychological memory, the ability to recall certain events, emotions, and relations. When we speak of memory as a social and historical process, we are referring to collective memory and/or political memory.

The mechanisms of forgetting in collective and political memory are different than in neuropsychological memory. While suppression of experiences or emotions often happens unconsciously or subconsciously in neuropsychological 
memory (Koutstaal \& Schacter 1997), in political memory it most often happens as a conscious event. In cases of trauma, there is often mental suppression of the event as a neuropsychological response to the extreme fear, pain, and disturbance of the event; however, victims of trauma are not always able to block out the occurrence of a traumatic event (or multiple events). In this case, one of two things may occur. Victims may unconsciously distort memories as a way of coping with their trauma (ibid.), or they may choose to consciously omit the traumatic event from their own history, which later leads to the omission of this event from collective history and memory. Further, even if an individual chooses not to silence his or her own narrative, the collective may choose to "enforce silence" in order to whitewash or forget historical trauma (Liem 2007).

Similarly, when we consider the process of remembering, we can see a subconscious effort to remember an event or experience in neuropsychological memory (Koutstaal \& Schacter 1997), and, in the sociopolitical sense, a conscious effort to memorialize, explain, or relive the moment in political memory. We can thus further differentiate neuropsychological memory and political memory by stating that the former is an involuntary neurological process and a reflexive response to the experiences of the individual, while the latter is a voluntary and conscious response by the individual to his/her own experiences and incorporated into that of the collective.

\section{MEMORY IN GENOCIDE}

This paper considers, in particular, the case of genocide, which is a particularly traumatic event. The experience of genocide creates many traumas for victims and survivors, as well as perpetrators. As a result, when it comes to genocide, both neuropsychological and political memory are extremely fragile and complicated processes.

Despite the incredibly traumatic aspects of genocide, many survivors are still able to recount their experiences, ${ }^{1}$ which proves that genocide in its entirety is rarely suppressed. This is possibly due to the longevity of some genocides, but also possibly due to the process of genocide, which generally employs incremental changes that, over time, lead up to exterminatory policies and/or actions.

In terms of political memory, the process of recounting survivors' experiences is a way of remembering the events of a genocide, usually so that they will not be forgotten, and future generations will heed the warning of the past. But also, the specific stories told by survivors hold a particular relevance to what is remembered as a collective. Certain experiences, emotions, and thoughts may be shared within the collective, and thus these shared aspects of memory become more salient in the collective history of the genocide (or collective memory). 
Consider the opposite when we think about forgetting; survivors, aware of many traumatic events, but perhaps unwilling to share all of them, choose to omit certain stories. This may be because they trigger emotions of discomfort, pain, fear, anxiety, and even shame or guilt. It may also be because these stories or the emotions tied to them feel too personal to share. As mentioned, shame or guilt can make these stories seem like they are unacceptable or punishable (if they were ever to be revealed), causing survivors to feel as though they must hide these events from others.

\section{TRAUMA AND THE TABOO}

In particular, the pain and discomfort of trauma can be compounded by the guilt and shame that surrounds the taboo - forbidden or unspeakable acts as well as non-normative events and experiences (Wiseman \& Metzl \& Barber 2006). Instead of merely feeling the guilt of survival, victims who have also been subjected to taboo traumatic experiences may feel the aforementioned guilt, as well as the pain and discomfort of the traumatic event, and additional guilt and shame from having been a participant (whether willingly or unwillingly) in an activity that is considered taboo. In addition, there is loneliness and guilt from not being able to share the experience with others, and fear of being found. As mentioned previously, these emotions of guilt, shame, discomfort, and even anger can lead to self-silencing and the silencing of others who shared the experience (ibid.).

Consider, for example, the hypothetical case of a mother who has nothing to feed her children in war. She may choose to steal food to help her family to survive but, given the dire circumstances, may have to steal from fellow victims, something which is considered wrong on multiple levels. While there may be those who might understand the mother's plight and sympathize with her, there are also others who will object to her actions as they were premeditated and increased the suffering of others. Furthermore, these actions could potentially be considered legally non-normative and punishable as theft.

Let us consider another hypothetical example, this time a more serious one. A young man is fleeing soldiers who are targeting him and others like him, based on ethnicity. He knows that there is nothing he can do to stop them from trying to kill him. Along with him is his elderly father, who cannot run as fast as him. He is faced with two choices: to remain at his father's pace and be killed or leave his father behind and survive. Either way, the young man will suffer greatly and his father will die, but in only one case can the young man survive. The decision to leave his father behind is unquestionably non-normative, perhaps 
not legally (as in the prior example), but certainly morally. And, much more so than the prior example, this action is considered taboo, as sacrificing the life of another, especially one's own father, is generally considered an unspeakable and shameful act in most cultures and societies. ${ }^{2}$

Both examples described above are wrong, in a sense (whether legally or morally), but at the same time represent hard decisions that sometimes must be taken in extenuating circumstances. However, the existence of extenuating circumstances does not necessarily liberate the actor from feelings of guilt or blame, and as noted, the normative framework within which these actions occur often adds extra feelings of guilt and shame.

\section{CASE STUDY: SEXUAL VIOLENCE IN THE HOLOCAUST}

When we look at cases of trauma in political memory, there are few that stand out more than those in genocide. The Holocaust, considered by many as the embodiment of genocide, presents many strong examples of trauma that shaped political memory in history. This paper will focus on one such example, that of sexual violence.

Research on sexual violence in the Holocaust is a fairly recent development, having begun in the 1980s and only gaining traction in the last decade or two (Hedgepeth \& Saidel 2010). This begs the question: if Holocaust and genocide studies are a relatively older field (almost a century old), why is this area of Holocaust studies so underdeveloped?

A review of the literature presents a number of potential answers. These answers can be distilled into three main explanations. The first is the morality of the topic. Sex, in general, is considered taboo; this means that sexual violence is extra taboo, as it is not only an intimate act but a violent one (Herzog 2009). For history and research, this means that any inquiries into questions of sex and sexual violence that are considered non-essential are often discouraged.

The second explanation has to do with the timing of social movements. Much of the research on sexual violence in the Holocaust resulted from inquiries by scholars in the fields of women's studies, and gender and sexuality studies. However, these feminists' movements did not gain their own place in academia until after the second wave of feminism (after the 1960s), which was after the initial phase of Holocaust research and analysis had been done. In the 1980s, equity and liberal feminism gained popularity, and research on gender and sex swelled in universities. With this trend came the revisiting of historical events, and the analysis of phenomena through a lens of gender and sexuality. We see the rise of strains of feminism coincide with the rise of feminist theories and 
analyses of the Holocaust, particularly when we look at the rise of the third wave of feminism in the 1990s. Scholars such as Susan Jeffords (1991) and Judith Baumel (1999) performed early research into the topic, making way for the boom in research that was ushered in with the new millennium. If research exists on the topic today, it is only because of efforts to support the feminist theory in academia and the efforts of early scholars in the topic to revisit questions of gender in the Holocaust.

The third and final explanation for lack of data on sexual violence in the Holocaust is the silence of victims on the topic. As Thomas Kühne suggests, "[s] exual violence during the Holocaust has long been the subject of the wildest fantasies or impermeable taboos ... facilitated by the silence of surviving but ashamed victims of Nazi sexual exploitation" (Kühne 2012). Victims have largely chosen to keep their silence because, as previously noted, the topic is taboo, and arouses feelings of guilt, fear, and shame. In addition to these emotions, victims are rarely asked about sexual violence in interviews, making it easier for them to maintain their silence and making them feel as though the experience is not a common one. This is further compounded by the desire to forget, leading them to omit such stories from their experience by conscious choice.

All of this, however, does not mean we do not have any data on sexual violence in the Holocaust; it simply means that it is fairly limited, at least for the time being. Despite this limitation, however, there are three actions related to the trauma of sexual violence in genocide, of which sufficient data has been garnered and which I can thus describe in this paper.

\section{Rape}

Rape is, quite often, the most common type of sexual violence that occurs in genocide, and the Holocaust is no exception to this (Burds 2009; Herzog 2009; Baumel 1999; Jeffords 1991). However, in the case of the Holocaust and World War II, there were multiple sides perpetrating rape, depending on location and year. In the years preceding World War II and during the early years of the war, it was German soldiers perpetrating rape, across Central and Eastern Europe; in middle years, this was divided into sexual assault committed in ghettos and camps in Central Europe (namely, Poland), and war rape occurring in the Soviet Union (Mühlhäuser 2017). In late years of the war, Russian troops, moving across Eastern Europe and advancing on Germany committed atrocities including rape as they moved along (Mühlhäuser 2017; Burds 2009). As made clear through later testimonies taken of survivors, the victims of rape were mainly Jewish (although non-Jewish women were also raped) (Banwell 2016), 
mostly of Slavic or Polish ethnicity. ${ }^{3}$ On rare occasions, boys were targeted by German soldiers, but it was rare for such instances to culminate in rape and usually stopped at molestation. ${ }^{4}$

\section{Prostitution}

Prostitution, while less common than rape, is well-documented in the Holocaust, thanks to the bureaucratic efforts of the German Reich. Reflecting the values and mentality of the Reich, the Wehrmacht created military brothels for forces in the East, making prostitution not only an institutionalized but also highly regulated and almost ritualized practice (Timm 2002). Dagmar Herzog's work on sexuality in the Third Reich expands on this mentality and shows how this practice was meant to encourage productivity, masculinity, and satisfaction among German troops in the East (Herzog 2005). Robert Sommer's book, Das $K Z$-Bordell, has also been notable in documenting the existence of concentration camp brothels, drawing on German and Austrian sources (Sommer 2009).

However, the other side of this clinical operation were the experiences of sex workers. Many were incentivized into service, inmates who were offered "better" positions in concentration camps if they served 3 to 6 months in a military brothel (ibid.). Some were sex workers before working in military brothels, others were simply non-Jewish women who were deemed "acceptable" for intimacy with German soldiers.

In addition to the institutionalized practice of prostitution, there were also informal sexual economies in ghettos and camps, where sexual favors or actions could be exchanged for resources or other favors. While little work has been done on this aspect, Anna Hájková's study of the sexual economy present at Theresienstadt Ghetto presents an opening into further research of this kind, which is much needed at this time (Hájková 2013). Interestingly, Hájková's work highlights that "while sexual barter often was motivated at first by sheer necessity ... the barter often developed a snowball dynamic, coloring many interactions and expectations" (ibid.: 504). However, the lack of additional research on the topic and lack of details on prostitution in survivors' testimonies presents a dilemma that can only be solved through second-hand testimonies or research of primary source documents that might substantiate the existence of this phenomenon further. 


\section{Reproductive violence}

In addition to the abovementioned forms of sexual violence, we can also examine reproductive violence as another form of sexual violence imposed by the Nazis during the Holocaust. Reproductive violence can refer to the harm (including removal) of reproductive organs, forced impregnation, forced abortion, and other denials of reproductive rights.

The most prevalent form of reproductive abuse during the Nazi regime was the direct denial of reproductive rights, particularly the right of some groups to have children. During World War II, Nazi policy specifically targeted Jewish women; in addition to the ways mentioned above, Nazi policy banned all births of Jewish children, to the point where "about 320,000 German persons with 'lives unworthy of life' were sterilized under the terms of the sterilization law" (Chelouche 2007: 203).

In addition to forced sterilization and persecutorial laws, the reproduction of the Jewish community was halted in its tracks due to Nazi policies regarding the youngest generation of Jews. Jewish infants and children born during the Holocaust had a very low chance of survival, due to their identity and the high probability that they would be chosen for "selection" - that is, death (see Holocaust Encyclopedia). As the survival rate for infants in the Holocaust was particularly low, women who had children during the genocide sometimes resorted to killing their infants, to avoid having them die of starvation or disease.

Additionally, having a child could pose a danger to pregnant mothers. In many cases, "the only way the mother could escape the death sentence was by undergoing a secret abortion or by suffocating the newborn, to prevent detection of the birth as anything other than a 'still birth,' and to protect all involved in saving the mother's life" (Weisz \& Kwiet 2018: 2). As such, there were women who faced an unimaginable choice: jeopardizing their own lives to try to raise a child in a ghetto or concentration camp, or kill their unborn child in order to survive.

A final challenge was that of women who were raped or who had accidentally gotten pregnant, who sometimes chose to resort to back-alley abortions, to avoid having children in these terrible conditions, and to avoid being sent to the gas chambers or otherwise killed for being pregnant (and therefore weak or unfit for labor). While German doctors were generally unopposed to ending pregnancies through abortion, many Jewish doctors expressed their discontent at performing these procedures, whether officially or under clandestine conditions. As one Jewish doctor, Dr. Aharon Peretz, stated, "I was forced to conclude that in the ghetto there was no way out except to abort these pregnant women" (Chelouche 2007: 204). Another Jewish doctor who operated on women in Auschwitz 
stated, "No one will ever know what it meant to me to destroy these babies" (ibid.). Consequently, we can see how this type of violence destroyed not only the victim but also the "perpetrator" - or rather, the facilitator of violence, who was often forced into such actions.

\section{REMEMBERING SEXUAL VIOLENCE}

What then does this mean for how we remember sexual violence in the Holocaust? The aforementioned sections present what researchers now know of these topics, but where do they fit into public and political memory of the Holocaust?

Due to the issue of the taboo, these events - and other instances of sexual violence - have been suppressed in the public memory of the Holocaust. The rise of the \#MeToo movement has allowed a more open discussion of sexual violence, but this still does not take away the disturbing aspect of these crimes. In terms of political memory and history, a stronger case is being made for why we should consider these crimes as a part of the methodology of genocide; however, until that argument is proven, sexual violence is unlikely to be thought of as a tool of genocide.

The reluctance of survivors to talk about sexual violence is somewhat lifting - perhaps due to changes in social values or political mood - but this is not enough, as many survivors have already passed away, taking their stories, memories, and experiences with them.

\section{FORGETTING SEXUAL VIOLENCE}

The converse of memorializing sexual violence in the Holocaust - purposely forgetting it - is still very, very real. While researchers have made an attempt to ameliorate this, there are few who wish to remember such a dark chapter. After all, if prior generations have deemed it worth forgetting, it may be best to let it fade away as was originally intended.

This raises two questions. The first is: Who gets to determine what is remembered? If it is historians, memory should be inclusive of all events that transpired, good and bad. If it is those who experienced the events, then memory is bound to be quite polarized, and have several different versions. If it is only the victims, we lose the danger of polarization but risk the danger of bias. In the latter two cases, we risk the danger of losing swaths of history to selective memory, as it is not (purportedly) unbiased third parties who determine what should and should not be remembered. 
The second question is how we remember atrocity without dishonoring the victims. This is an important consideration, since memory attempts to be neutral, and not insulting or harmful to those who have already suffered. Additionally, many victims do not (or did not) want to share their stories for fear of being judged, shamed, or invalidated. The best way to go forth, then, is to provide context to the actions and reactions of victims. In the case of rape, for example, a victim may feel ashamed for not reporting her rape, but it is essential to remember that had she reported it (during the Holocaust), she would have likely been killed for insubordination against a German soldier.

\section{CONCLUSION}

The decision to remember some things while forgetting others is, in political memory, a very conscious process. And, as the above analysis revealed, there are some events that are considered more horrifying, shameful, or painful than others, even in atrocity, making individuals more likely to hide or suppress these experiences from their communities, historians, and researchers. This act of selectively remembering and forgetting events can create a challenge that neither the researchers nor the public may not be aware of, the creation of a false history, which omits variables that may be a key to understanding larger processes and phenomena.

It is thus up to scholars and researchers to delve deeper and, when confronted with experiences that appear to spark shame or guilt, to proceed with caution but proceed, nonetheless. Although there are some actions and decisions people may wish to take back, it is important, if we want to understand the past, to allow all things to come to light.

\section{NOTES}

1 The existence of the USC Shoah Foundation's Visual History Archive and its some tens of thousands of testimonies is proof of the ability and willingness of genocide survivors to recall and recount their stories.

2 While there is limited academic literature on patricide or other forms of parricide during genocide and war, cases like the one illustrated herein are not uncommon. Even if they are not overt cases of parricide, or simply are passive allowances of death, we may observe them in individual testimonies of survivors. Take, for example, the case of Elie Wiesel's reaction to his father's death as described in Night: "I did not weep ... I was out of tears. And deep inside me ... I might have found something like: Free at last!" (Wiesel 1958: 112). Although mild among examples, Wiesel's case illustrates that even the most dedicated of sons may feel relieved from the burden 
of the company of an ailing, elderly father in the midst of war, and that the death of a father - although painful at first - may also be considered a blessing (although, again, this may be morally shameful).

3 See USC Shoah Foundation, University of Southern California, available at https:// sfi.usc.edu/, last accessed on 7 April 2021.

${ }^{4}$ Due to confidentiality clauses, specific interviews may not be cited here, but are available for researcher perusal through the above citation, at the USC Shoah Foundation.

\section{REFERENCES}

Banwell, Stacy 2016. Rassenschande, Genocide and the Reproductive Jewish Body: Examining the Use of Rape and Sexualized Violence against Jewish Women during the Holocaust? Journal of Modern Jewish Studies, Vol. 15, No. 2, pp. 208227. http://dx.doi.org/10.1080/14725886.2015.1049853.

Baumel, Judith Tydor 1999. Women's Agency and Survival Strategies during the Holocaust. Women's Studies International Forum, Vol. 22, No. 3, pp. 329-347. http:// dx.doi.org/10.1016/S0277-5395(99)00032-1.

Burds, Jeffrey 2009. Sexual Violence in Europe in World War II, 1939-1945. Politics \& Society, Vol. 37, No. 1, pp. 35-73. http://dx.doi.org/10.1177/1059601108329751.

Chelouche, Tessa 2007. Doctors, Pregnancy, Childbirth and Abortion during the Third Reich. Israel Medical Association Journal, Vol. 9, No. 3, pp. 202-206. Available at https://www.ima.org.il/FilesUploadPublic/IMAJ/0/45/22849.pdf, last accessed on 7 April 2021.

Hájková, Anna 2013. Sexual Barter in Times of Genocide: Negotiating the Sexual Economy of the Theresienstadt Ghetto. Signs: Journal of Women in Culture and Society, Vol. 38, No. 3, pp. 503-533. https://doi.org/10.1086/668607.

Hedgepeth, Sonja M. \& Saidel, Rochelle G. (eds.) 2010. Sexual Violence against Jewish Women during the Holocaust. 1 edition. Waltham, MA: Brandeis University Press $\&$ Hanover, N.H.: University Press of New England.

Herzog, Dagmar 2005. Sex after Fascism: Memory and Morality in Twentieth-Century Germany. Princeton \& Oxford: Princeton University Press.

Herzog, Dagmar 2009. Brutality and Desire - War and Sexuality in Europe's Twentieth Century. London: Palgrave Macmillan. https://doi.org/10.1057/9780230234291.

Holocaust Encyclopedia = Children During the Holocaust. United States Holocaust Memorial Museum. Available at https://encyclopedia.ushmm.org/content/en/ article/children-during-the-holocaust, last accessed on 7 April 2021.

Jeffords, Susan 1991. Performative Masculinities, or, 'After a Few Times You Won't Be Afraid of Rape at All.' Discourse, Vol. 13, No. 2, pp. 102-118. Available at https:// www.jstor.org/stable/41389188, last accessed on 7 April 2021.

Koutstaal, Wilma \& Schacter, Daniel L. 1997. Inaccuracy and Inaccessibility in Memory Retrieval: Contributions from Cognitive Psychology and Neuropsychology. In: P.S. Appelbaum \& L.A. Uyehara \& M.R. Elin (eds.) Trauma and Memory: Clinical and Legal Controversies. New York: Oxford University Press, pp. 93-137. 
Kühne, Thomas 2012. Review of Das KZ-Bordell. Sexuelle Zwangsarbeit in nationalsozialistischen Konzentrationslagern by Robert Sommer. Central European History, Vol. 45, No. 3, pp. 593-595. Available at http://www.jstor.org/stable/23270538, last accessed on 7 April 2021.

Liem, Ramsay 2007. Silencing Historical Trauma: The Politics and Psychology of Memory and Voice. Peace and Conflict: Journal of Peace Psychology, Vol. 13, No. 2, pp. 153-174. http://dx.doi.org/10.1080/10781910701271200.

Mühlhäuser, Regina 2017. Reframing Sexual Violence as a Weapon and Strategy of War: The Case of the German Wehrmacht during the War and Genocide in the Soviet Union, 1941-1944. Journal of the History of Sexuality, Vol. 26, No. 3, pp. 366-401. http://dx.doi.org/10.7560/JHS26302.

Sommer, Robert 2009. Das KZ-Bordell: Sexuelle Zwangsarbeit in nationalsozialistischen Konzentrationslagern. Paderborn: Ferdinand Schöningh.

Timm, Annette F. 2002. Sex with a Purpose: Prostitution, Venereal Disease, and Militarized Masculinity in the Third Reich. Journal of the History of Sexuality, Vol. 11, No. 1/2, pp. 223-255. http://dx.doi.org/10.1353/sex.2002.0014.

Verovšek, Peter J. 2016. Collective Memory, Politics, and the Influence of the Past: The Politics of Memory as a Research Paradigm. Politics, Groups, and Identities, Vol. 4, No. 3, pp. 529-543. http://dx.doi.org/10.1080/21565503.2016.1167094.

Weisz, George M. \& Kwiet, Konrad 2018. Managing Pregnancy in Nazi Concentration Camps: The Role of Two Jewish Doctors. Rambam Maimonides Medical Journal, Vol. 9, No. 3, e0026. http://dx.doi.org/10.5041/RMMJ.10347.

Wiesel, Elie 1958. Night. Transl. by Marion Wiesel. Paris: Les Editions de Minuit.

Wiseman, Hadas \& Metzl, Einat \& Barber, Jacques P. 2006. Anger, Guilt, and Intergenerational Communication of Trauma in the Interpersonal Narratives of Second Generation Holocaust Survivors. American Journal of Orthopsychiatry, Vol. 76, No. 2, pp. 176-184. http://dx.doi.org/10.1037/0002-9432.76.2.176.

Maya Camargo-Vemuri is Adjunct Professor at the United States Naval Academy. She is currently working on her $\mathrm{PhD}$ at the Johns Hopkins University School of Advanced International Studies in Washington, DC. Her dissertation focuses on repertoires of violence in genocide. Her research areas are genocide and ethnic cleansing, mass violence, civilian victimization, authoritarianism, totalitarianism, and political identity. She is also interested in political memory and history as they relate to genocide, atrocity, and other human rights violations.

mcamarg2@jhu.edu 